Number of article: 623

CODEN: MINSC5

Received: June 6, 2019

Accepted: July 8, 2019
Mechanical Engineering - Scientific Journal, Vol. 37, No. 1-2, pp. 99-105 (2019)

ISSN $1857-5293$

e-ISSN 1857-9191

UDC: $725.21 .05: 624.012 .6]:[519.612: 531.2$

https://doi.org/10.55302/MESJ19371-2623099t

Original scientific paper

\title{
CONCEPT FOR STUDENT GLASS PAVILION
}

\section{Bojana Trajanoska, Elisaveta Dončeva, Daniela Pana, Hristijan Gjorgievski}

\author{
Faculty of Mechanical Engineering, "Ss. Cyril and Methodius" University in Skopje, \\ P.O. box 464, MK-1001, Skopje, Republic of North Macedonia \\ bojana.trajanoska@mf.edu.mk
}

\begin{abstract}
A b s t r a c t: Contemporary architecture and engineering are based on combining structural glass and steel, where glass is used for its transparency and steel for its strength. The intention behind this pavilion concept is decreasing the lack of modern glass structures in our surrounding. This article describes the FE modelling and analysis of a glass structure planned to be located in the technical campus of the Faculty of Mechanical Engineering in Skopje. The final exterior of the structure is consisted of five glass frames adhesively bonded and mechanically connected with bolts which give the support of the structure and hold the façade and roof panels. Different scenarios were presented regarding the stability and safety of the glass structure. The carried out FEM simulations are presented, based on predicted static loads, according to the pavilion's location and the climatic parameters. At the end of this article, visual representation of the CAD model within the campus space is given.
\end{abstract}

Key words: glass pavilion; steel connection; structural glass; state of the art; finite element analysis

\section{КОНЦЕПТ ЗА СТУДЕНТСКИ СТАКЛЕН ПАВИЛЈОН}

А п с т р а к т: Модерната архитектура и инженерство се темелат на комбинирањето на конструктивно стакло и челик, при што стаклото се користи поради провидноста, а челикот поради својата јакост. Овој концепт за студентски павилјон произлегува од недостигот на модерни стаклени конструкции во нашата околина. Трудот го опишува моделирањето и анализата со метод на конечни елементи на конструкција од стакло планирана да се постави во техничкиот кампус на Машинскиот факултет во Скопје. Крајниот надворешен изглед на конструкцијата се состои од пет стаклени рамки атхезивно споени и механички зајакнати со завртки, кои го даваат скелетот на конструкцијата на која се поставуваат стаклените фасадни и покривни панели. Во поглед на стабилноста и безбедноста на стаклената конструкција, прикажани се различни конструктивни случаи. Презентирани се извршените симулации со примена на методот на конечни елементи, при што статичките оптоварувања се пресметани врз основа на локацијата и климатските услови. Визуелната репрезентација на моделот $\mathrm{CAD}$ е прикажана на крајот од трудот каде што се забележува хармоничното совпаѓање на конструкцијата со околината на техничкиот кампус.

Клучни зборови: стаклен павилјон; челични врски; конструктивно стакло; преглед на постојните трендови; метод на конечни елементи

\section{INTRODUCTION}

In the modern architecture and engineering, structural glass elements tend to replace the traditional structural materials, like steel or concrete. This dramatic change brought a new trend in glass roofs and external glass frames in home living. The two primary factors for using structural glass over any other building materials are innovative daylighting and transparency, which empower a sense of unlimited space [2, 5]. Aditionally these reasons are basic requirements when designingл a student friendly environment for continuous learning or group working.

Although structural glass cannot be compared with steel in terms of durability and toughness, it is the only transparent material with high strength that can be used in many contemporary load-bearing structures. Strength values for structural glass design and its application are summarized in Table 1. 
Table 1

Strength values of structural glass [4]

$(\mathrm{MPa})$

\begin{tabular}{lc}
\hline \hline Compressive strength & $880-930$ \\
Tensile strength & $30-90$ \\
Bending strength & $30-100$ \\
\hline \hline
\end{tabular}

The high brittleness of the structural glass makes it risky to use in crowded locations because under tensile loads, any surface crack might cause failure of the glass element.
One of the common solutions regarding this problem is using treatment such as annealing, tempering and heat strengthening, as well as laminating in order to improve the mechanical properties and structural characteristics. Laminated glass has become extensively used as a safety glass in modern hybrid structures due to the polymeric interlayer that holds together the elements pieces when shattered. The interlayer, typically PVB or EVA, keeps the glass plies together even broken, constraining from breaking into large sharp pieces. Different types of glass breaking are shown in Figure 1.

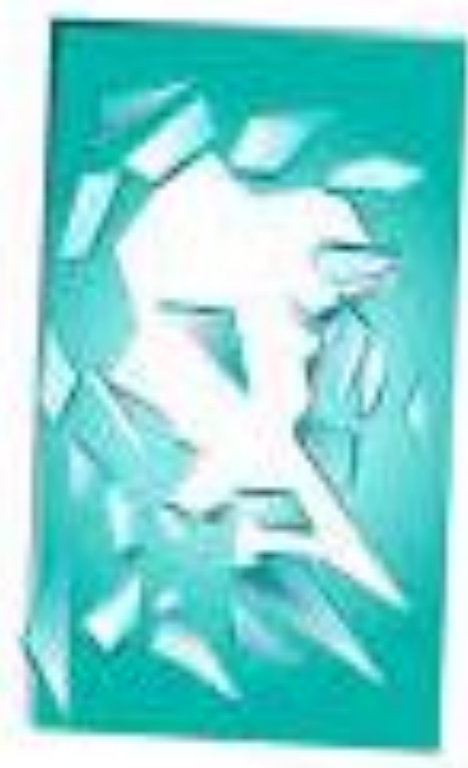

tempered

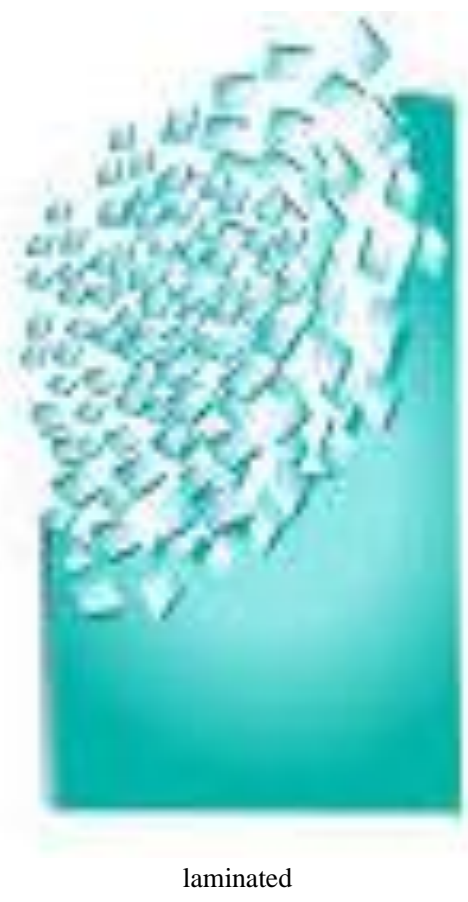

Fig. 1. Breaking of common glass types

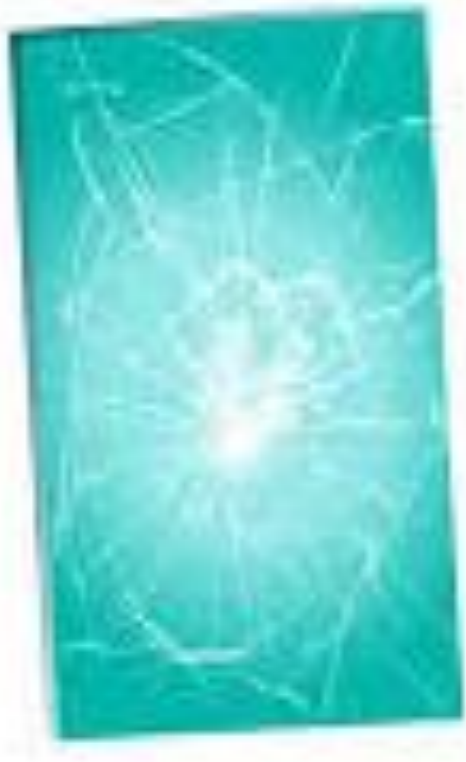

annealed
The low ductility and the high compressive strength of the glass allows connections with greater strength and hardness, like the ones with stainless steel. Bolted connections (Figure 2) are used for connecting glass elements where stress concentrations may occur. Regarding the performance of the bolt, forces up to $30 \mathrm{kN}$ can be transmitted per bolt [6]. In addition to prevent restraint forces, the number of bolts should be as minimal as possible in favor of greater bolt diameters.

Based on the above mentioned structural charateristic, the mechanical behavior the transparency and the inovative daylighting prospects of the structural safety glass as a laminated glass, it is chosen as the most adequate material for designing the stu- dent pavilion accommodating new modern concepts with psychological benefits.

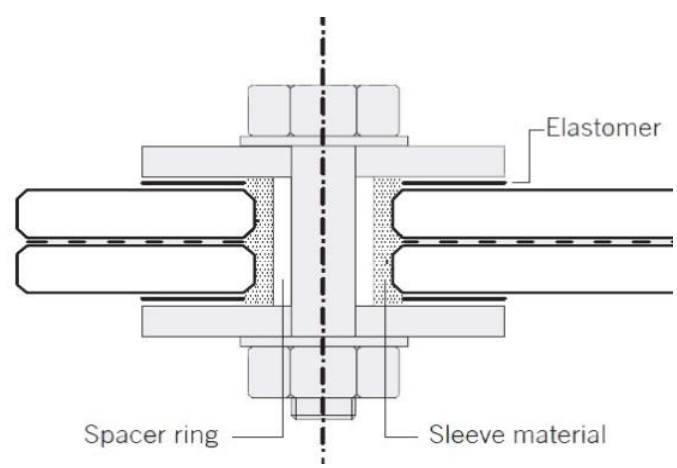

Fig. 2. Bolt connection [6] 


\section{CONCEPT}

The student glass pavilion idea arouse from the need of creative and inovative working space which students can use in their spare time at the technical campus of the Faculty of Mechanical Engineering in Skopje, and later the concept was introduced accordingly.

The glass pavilion is $5 \times 5 \times 2.5 \mathrm{~m}$, supported on a concrete fundament where steel groundwork is placed. The contact glass-steel is prevented with rubber installed inside the groundwork. The glass columns and beams are formed of tempered glass, joint with PVB, giving a high strength laminated panel (Figure 3).

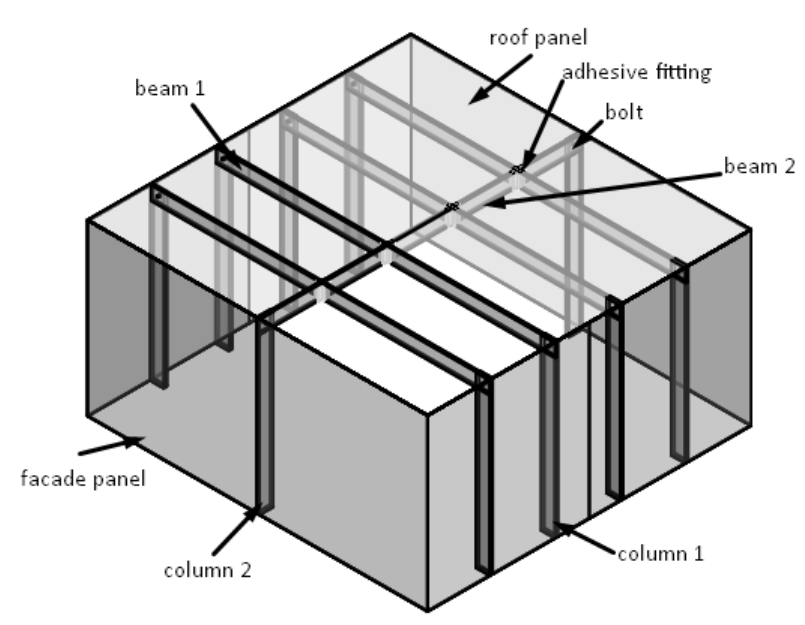

Fig. 3. Structural members

The lateral and horizontal glass panels that confine the structure consists of one fully tempered glass ply and heat-strengthened ply with inner PVB layer. Dimensions of the structural members are given in Table 2.

When designing, a previously detailed plan is required. Furthermore, a comprehensive research and calculations were carried out in order to realize the concept of glass pavilion. Finally, a flow diagram with various steps of work is presented (Figure 4).

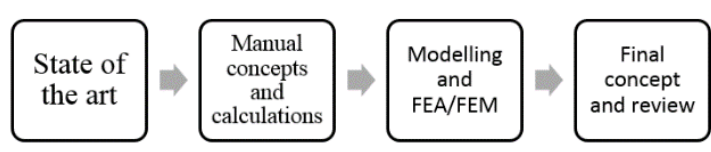

Fig. 4. Concept realization steps

A state of the art research has been done in the field of glass building construction. Wilson reviews the Glass Reading Room of the Arab Urban Development Institute in Riyadh, Saudi Arabia (Figure 5) [2]. The glass cube is formed of laminated glass panels, connected with friction grip connections in order to provide stability through the frame that carries the applied loads.

Table 2

\section{Dimensions of designed structural members}

\begin{tabular}{|c|c|c|}
\hline $\begin{array}{l}\text { Structural } \\
\text { member }\end{array}$ & $\begin{array}{l}\text { Glass type, layer of } \\
\text { glass }(\mathrm{mm})\end{array}$ & $\begin{array}{c}\text { Dimensions } \\
\mathrm{L} \times \mathrm{W} \times \mathrm{H}(\mathrm{mm})\end{array}$ \\
\hline Column 1 & $\begin{array}{l}\text { fully tempered, } \\
\qquad 2 \times 10\end{array}$ & $200 \times 20 \times 2500$ \\
\hline Inner column 1 & $\begin{array}{l}\text { fully tempered, } \\
\qquad 4 \times 10\end{array}$ & $200 \times 40 \times 2300$ \\
\hline Beam 1 & $\begin{array}{l}\text { fully tempered, } \\
\qquad 4 \times 10\end{array}$ & $5000 \times 40 \times 200$ \\
\hline Column 2 & $\begin{array}{l}\text { fully tempered, } \\
\qquad 2 \times 10\end{array}$ & $200 \times 20 \times 2500$ \\
\hline Inner column 2 & $\begin{array}{l}\text { fully tempered, } \\
\qquad 4 \times 10\end{array}$ & $200 \times 40 \times 2300$ \\
\hline Beam 2 & $\begin{array}{l}\text { fully tempered, } \\
\qquad 4 \times 10\end{array}$ & $920 \times 40 \times 200$ \\
\hline Roof pane & $\begin{array}{l}\text { fully tempered } \\
1 \times 5+\text { heat } \\
\text { strengthened } \\
1 \times 5\end{array}$ & $2500 \times 1000 \times 10$ \\
\hline Façade pane & $\begin{array}{c}\text { fully tempered } \\
1 \times 10+\text { heat } \\
\text { strengthened } 1 \times 5\end{array}$ & $2500 \times 2500 \times 15$ \\
\hline
\end{tabular}

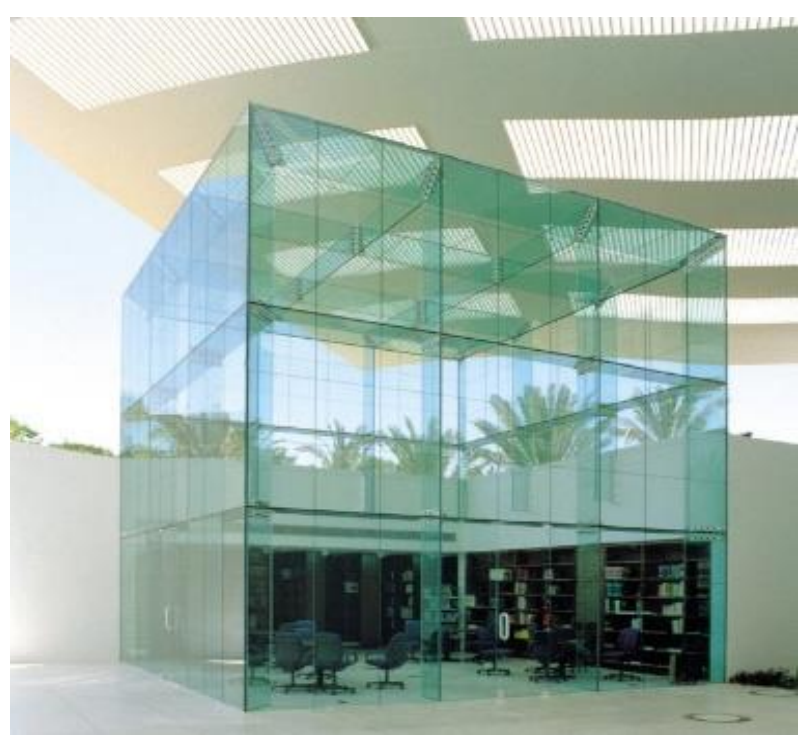

Fig. 5. Glass Reading Room in AUDI in Riyadh, Saudi Arabia [2]

In [10] the new pavilion located in Zurich, Switzerland (Figure 6) is analyzed). Matt-finished stainless-steel frame and colored but transparent glass, are the primary exterior details that give this polygonal-plan structure compliance with the environment and fulfill the illumination requirements. 


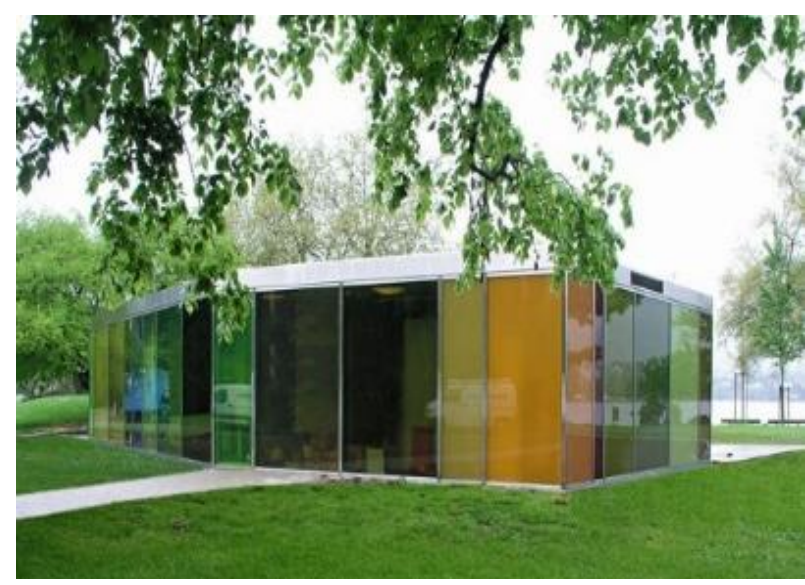

Fig. 6. The color glass pavilion in Zurich, Switzerland [10]

All glass enclosure is discussed in [3, 7], built at the Leibniz Institute for Solid State and Material Research in Dresden, Germany (Figure 7). Their main goal is to describe the arrangement of the structural members, frame assembly and final installlation. The fully glazed enclosure is made from laminated safety glass, bonded to the frame with a structural silicon adhesive as a joining technique. Hence, the glass corners are joint with acrylate adhesives, which give an exclusively transparent outlook.

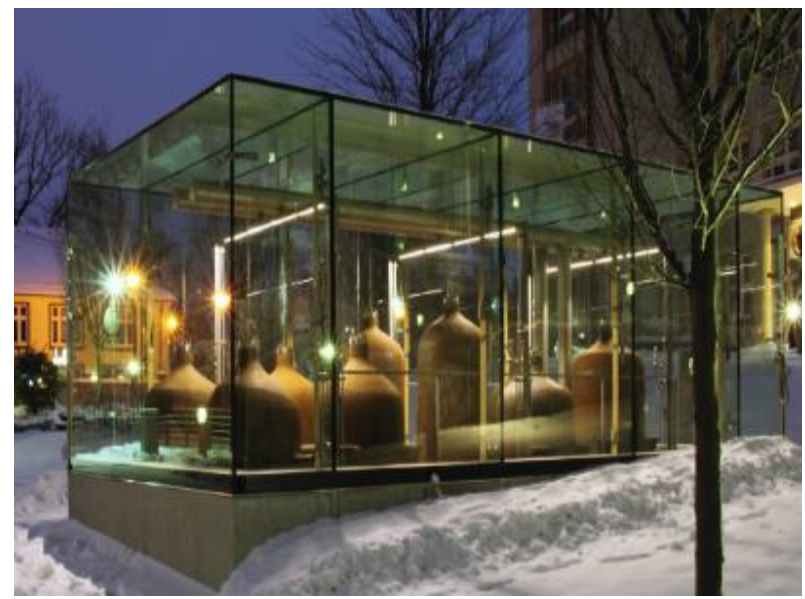

Fig. 7. All glass enclosure at Leibniz Institute in Dresden, Germany [3]

Breakthrough in the application of structural glass was building the Apple Inc glass cube, the Fifth Avenue, store located in New York City, which was the first of a kind [1]. The structure itself shows functionality and simplicity. First glass cube (Figure 8) connected the engineering with the art; the second cube (Figure 9), further enhanced that connection. The limiting factors of the production technologies of glass resulted in a glass cube with 164 units joined, forming a standing art piece [1].

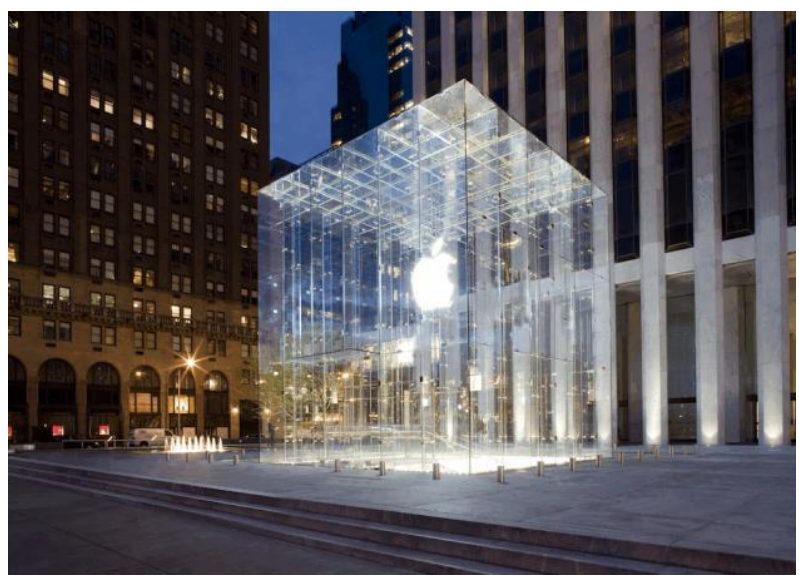

Fig. 8. Original glass cube - Apple store

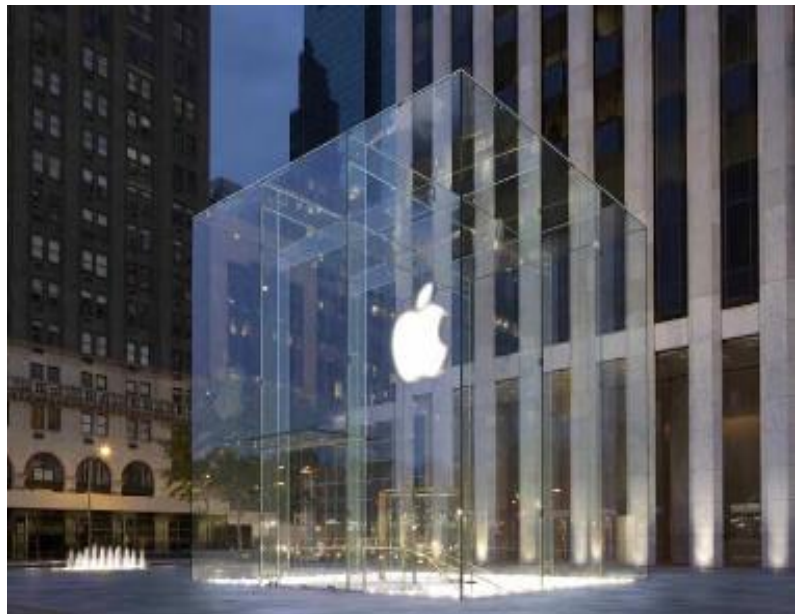

Fig. 9. New glass cube- Apple store

The advancement in the production technology of structural glass was validated with constructing the second glass cube. Thirty-five units joined together proved that glass production has moved forward. Comparing the two of them (Table 3), it is inevitable not to see the difference in the roof design. Two spanning beams with secondary roof beams from sides and between the spanning beams holed with roof fins. The façade panes were able to be as large as $15 \mathrm{~m} \times 3.6 \mathrm{~m}$, which gave the final look of the second glass cube.

The reduction of the number of the glass structural members in the new Apple store, led to fewer glass-steel connections. One of the few reasons for rebuilding this glass cube was to establish the new developed connection that holds the glass panes together (Figure 10). Before it was completed, a numerical analysis was run with particular attention to the interaction between the glass, interlayers and fittings. The connection model (Figure 11) confirmed the expected behavior of the joined materials [1] and let to a unique challenge- rebuilding the glass cube. 
Table 3

Comparison of the structural members of the two Apple glass cubes [1]

\begin{tabular}{lcc}
\hline \hline Building part & Cube 1 & Cube 2 \\
\hline Columns & $\begin{array}{c}5 \text { per elevation } \\
\times 4=20\end{array}$ & $\begin{array}{c}2 \text { per elevation } \\
\times 4=8\end{array}$ \\
$\begin{array}{l}\text { Façade panles } \\
\text { (incl. doors) }\end{array}$ & 72 & $\begin{array}{c}12+2 \text { doors }+2 \\
\text { side lights }=16\end{array}$ \\
Roof beams & 25 at $3.3 \mathrm{~mm}+10$ & 2 at $10 \mathrm{~mm}+7$ \\
& at $1.6 \mathrm{~m}=35$ & at $3.3 \mathrm{~m}=9$ \\
Roof panles & 36 & 3 \\
Entrance canopy & 1 & 1 \\
Subtotals & 109 panels & 20 panels \\
& 20 fin columns & 8 fin columns \\
& 35 beams & 7 beams \\
\hline Total & 164 glass units & 35 glass units \\
\hline \hline
\end{tabular}

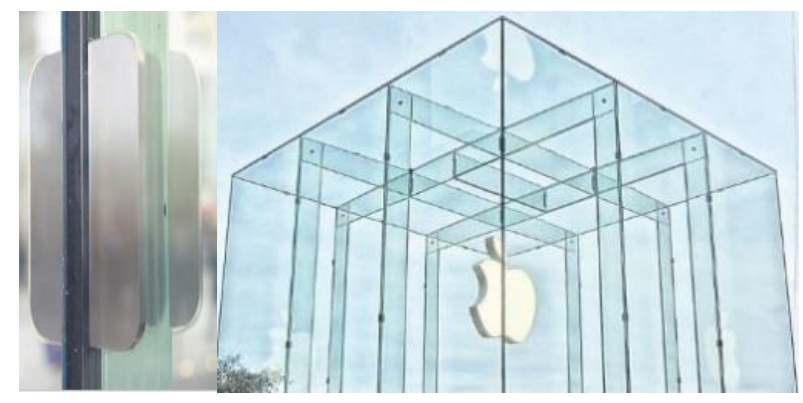

Fig. 10. New developed fitting [1]

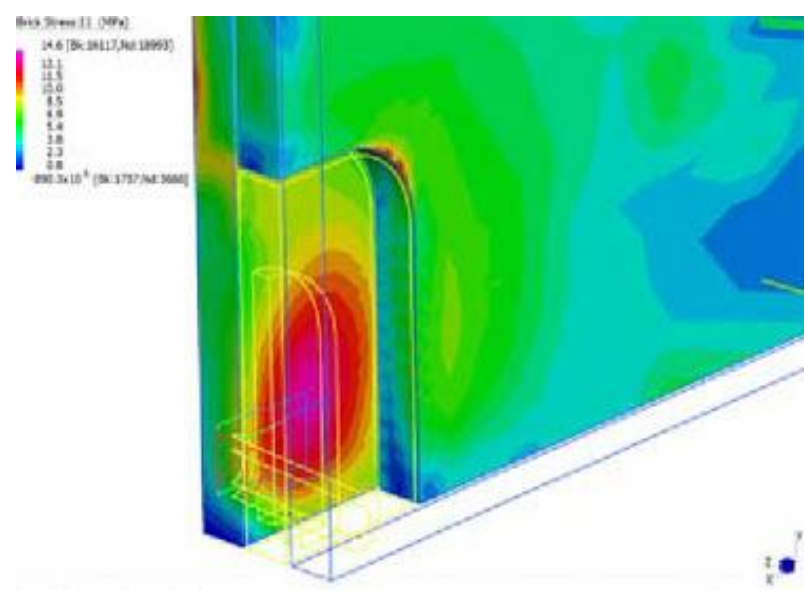

Fig. 11. Local connection model [1]

\section{STRUCTURAL ANALYSIS}

This paragraph shows the results of different analysis performed on these article subject concepts. Using laminated safety glass, all bearing elements were tested using FEM analysis, including the enclosed structure itself. The frame members, stated as glass beams and columns, are made of fully tempered glass layers, each with thickness $10 \mathrm{~mm}$. The glass frame ware tested separately, as a primary bearing column-beam assembly. Mainly, it was expected a local stress to occur between the glass and the stainless-steel connection, because of the different behavior of the materials under loading conditions (Figure12).

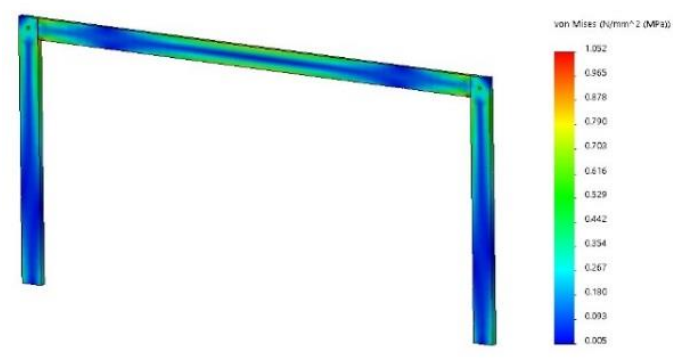

Fig. 12. Stress distribution of the structural frame

However, significant displacement was evaluated centrally on the glass beam, with maximum displacement of $0.182 \mathrm{~mm}$ (Figure 13).

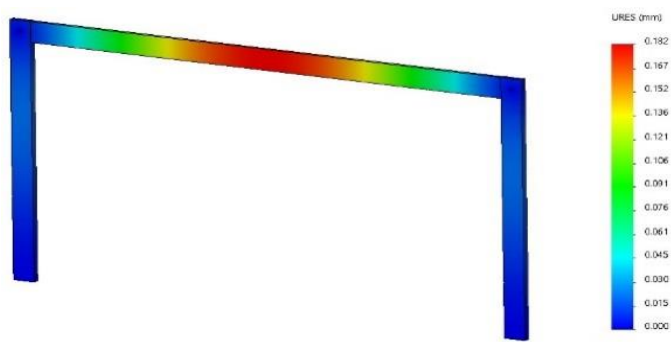

Fig. 13. Maximum displacement of the structural frame: column-beam

Regarding the above-analyzed factors, three different scenarios were examined under the same load conditions (Table 4).

Table 4

Scenarios for FEM analysis

Scenario No. Description

Scenario 1 Structured without support beam and column 2, roof panel thickness $10 \mathrm{~mm}$

Scenario 2 Structured with support beam and column 2, roof panel thickness $15 \mathrm{~mm}$

Scenario 3 Structured with support beams and five cross beams with adhesive fittings, roof panel thickness $10 \mathrm{~mm}$

A brief comparison of the FEM results is given in Table 5 and a significant explanation is summarized. 
Table 5

\begin{tabular}{lcc}
\multicolumn{3}{c}{ Comparison of FEM results } \\
\hline \hline Scenario & $\begin{array}{c}\text { Max. stress } \\
\text { (MPa) }\end{array}$ & $\begin{array}{c}\text { Max. displacement } \\
(\mathrm{mm})\end{array}$ \\
\hline Scenario 1 & 13.80 & 26.39 \\
Scenario 2 & 7.39 & 6.23 \\
Scenario 3 & 7.96 & 7.57 \\
\hline \hline
\end{tabular}

The stress distribution is present for each scenario and remarkably lower stresses were observed on the front and back façade panes of Scenarios 2 and 3 (Figures 16 and 18, respectively), when compared to stress result from the Scenario 1, shown in Figure 14

The displacement analysis of Scenario 1 presented in Figure 15 shows considerably larger displacement of the front and back façade panes under buckling behavior, while the rest members of the structure are sufficiently substantial for the suggested scenario. On the other hand, the results obtained from both, Scenarios 2 and 3, illustrate smaller displacement gradient (Figures 17 and 19, respectively).
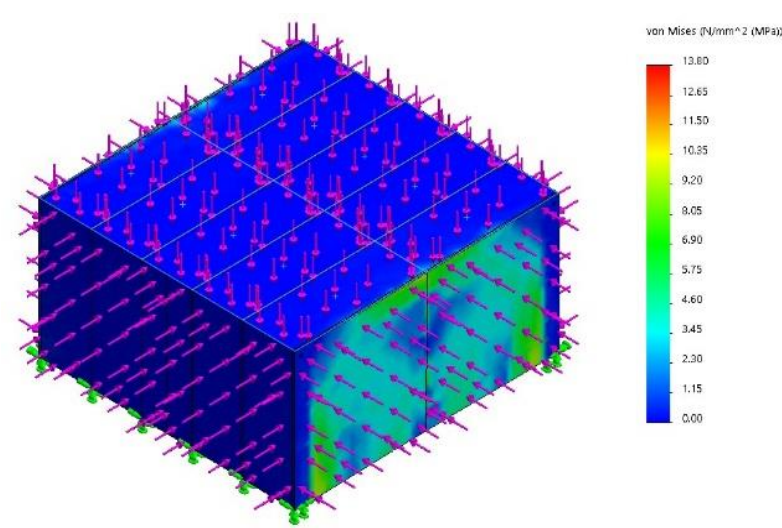

Fig. 14. Scenario 1 - Von Mises stress

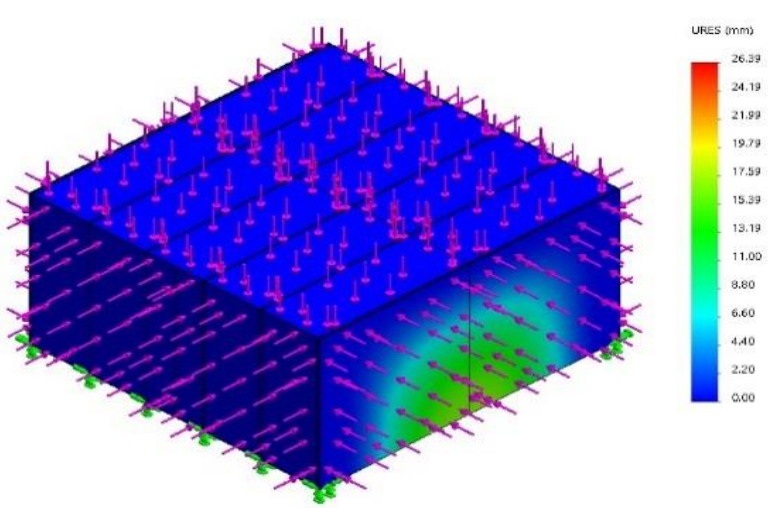

Fig. 15. Scenario 1 - Displacement

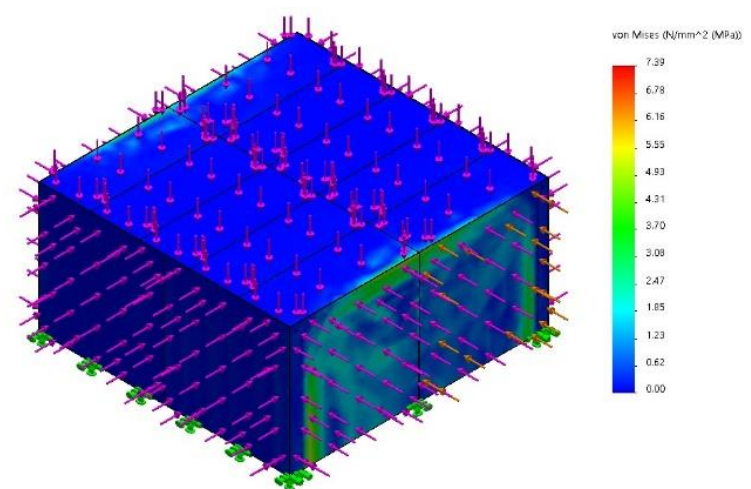

Fig. 16. Scenario 2 - Von Mises stress

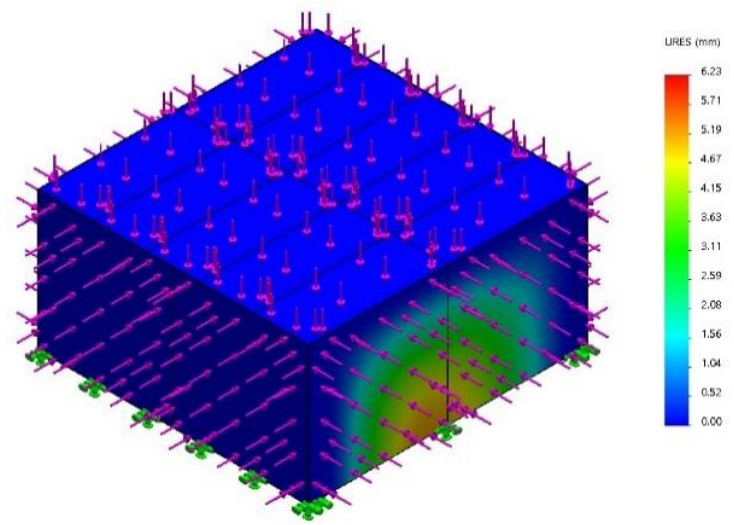

Fig. 17. Scenario 2 - Displacement

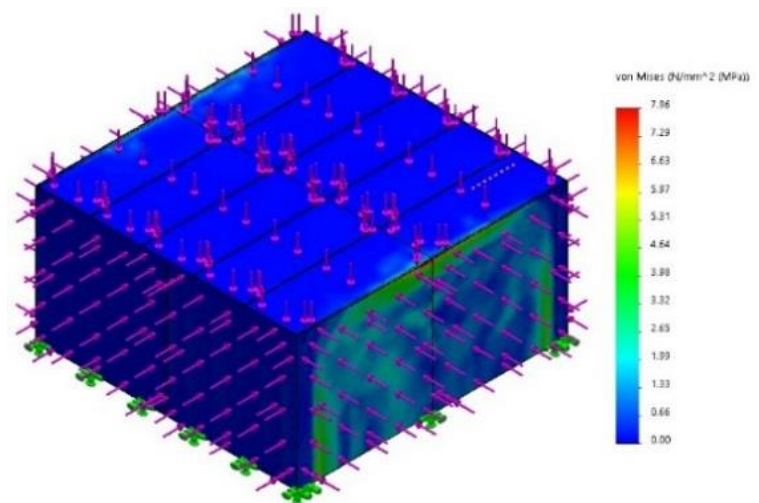

Fig. 18. Scenario 3 - Von Mises stress

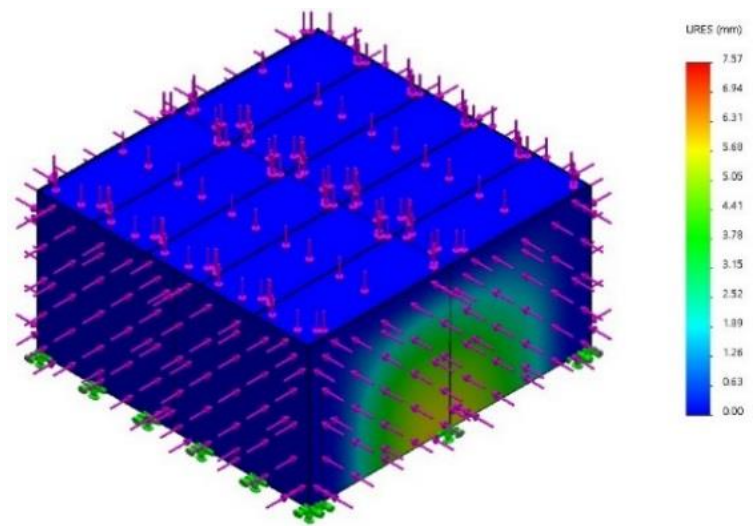

Fig. 19. Scenario 3 - Displacement 
The exemplify results are due to the additional central support frame (Scenario 1 is modeled without the support beams and columns).

Another conclusion can be outlined from the simulation analysis. As mentioned before, glass has high compressive strength, but it depends on the size of the glass panel [9]. The larger the size is the more chance of finding critical imperfections and defects in the glass element. The buckling phenomena in glass panels under compression is frequent problem in all glass structures [11]. Based on this knowledge, laminated glass columns are arranged on both, left and right side of the façade for support and preventing sudden failure. Considering these side columns arrangement, no significant stresses nor displacement were determined in none of the scenarios.

\section{CONCLUSIONS}

This comprehensive study on structural glass student pavilion opens the possibility for conversion of creative and innovative project. The mechanics and safety for this structure was proven by using FEM analysis on each scenario under static loads. Scenario 3 was chosen as an eventual structural solution for further detailed and accurate technical development (Figure 20).

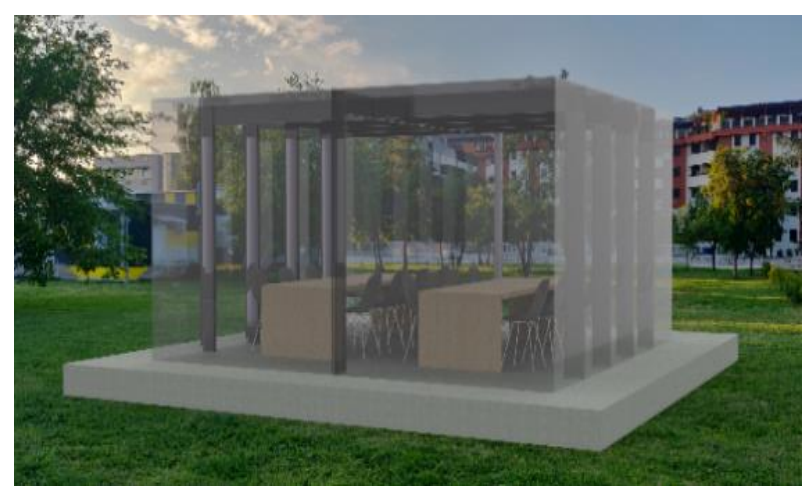

Fig. 20. Visual representation of the student glass pavilion located in the technical campus in Skopje

Furthermore, the preceding results of the stress and deformation that occurred in Scenario 3 were dependable and rational when choosing the final concept as well as the total weight of the glass structure.

The vast field of application of the glass structures is evaluated by the state of the art, which are serving different functions. While being the driving factor, safety is the main concern when designing and constructing glass structure. Simplicity and the ability to comply with the environment is one of the benefits of an all-glass structure, which implies on the physiological state of the users.

\section{REFERENCES}

[1] Bostick, C., O'Callaghan, J.: The Apple glass cube: Version 2.0, In book: Challenging Glass 3 \& Conference on Architectural and Structural Applications of Glass, Technical University (TU) Delft, The Netherlands, 2012.

[2] Wilson, P.: All-glass enclosures - Spaces for working and living, In book: Challenging Glass 4 \& COST Action TU0905 Final Conference, pp. 641-647, 2014.

[3] Weller, B, Nicklisch, F., Prautzsch, V. Döbbel, F., Rücker, S.: All glass enclosure with transparently bonded glass frames. In: Challenging Glass 2 - Conference on Architectural and Structural Applications of Glass, Bos, Louter, Veer (Eds.), TU Delft, May 2010.

[4] Fröling, M.: Strength design methods for glass structures, Doctoral thesis, Lund, Sweeden, Division of Structural Mechanics, Lund University, 2003, pp. 9-15.

[5] Louter, C., Bos, F., Belis, J., \& Lebet, J. P. (Eds.): Challenging Glass 4 \& COST Action TU0905 Final Conference. CRC Press, 2014.

[6] Wurm, J.: Glass Structures - Design and Construction of Self-supporting Skins, Birkhäuser Verlag, 2007.

[7] Weller, F., Nicklisch F.: Bonding of glass - Latest trends and research, In: Structures Congress, 2010 ASCE, Orlando, Florida, 2010.

[8] Trajanoska, B., Gavriloski, V., Bogatinoski, Z., Gavriloski. M.: State of the art in research of reinforced structural glass elements, Mechanical Engineering - Scientific Journal, vol. 33, 1, pp. 27-32 (2015).

[9] Morgan, T.: Aspects of Structural Glass, Institute of Structural Engineers, SE Counties Branch, 2010.

[10] Helzel, M., Taylor, I.: Stainless Steel and Glass, Euro Inox, The European Stainless Steel Development Association, Brussels, Belgium, 2008.

[11] Bedon, C., Amadio, C.: Stability of flat glass panels under combined in-plane compression and shear, In book: Challenging Glass 4 \& COST Action TU0905 Final Conference, Lausanne, Switzerland, 2014. 
